\title{
Mecanismos de alteración de las piedras de la Catedral de Granada, España
}

\author{
Alteration mechanisms on the stones \\ of the Catedral of Granada, Spain
}

MARTÍN, L.; BELLO, M. A. y MARTÍN, A.

Departamento de Química Analítica. Facultad de Química. Universidad de Sevilla

ESPAÑA

Fecha de recepción: 7-X-92.

\section{RESUMEN}

Se analizan los diversos mecanismos de alteración que actúan sobre los materiales pétreos usados en la Catedral de Granada.

Se estudia con detalle la acción del agua, influencia antropogénica, oscilaciones térmicas, factores de incompatibilidad, movimientos sísmicos y factores de tipo biológico.

\section{$S U M M A R Y$}

The diverse alteration mechanisms which operate on the stony materials of the Granada Cathedral have been analized.

The water action, anthropogenic influence, thermic oscillations, incompatibility factors, seismicity and biological factors have been considered.

\section{INTRODUCCIÓN}

En artículos publicados anteriormente sobre la Catedral de Granada, ha sido considerada la morfología macroscópica de alteración [1], la caracterización de los diversos materiales pétreos y los procesos de alteración que ocurren en el edificio [2], así como el comportamiento de los diversos tipos de piedras sometidas a ensayos de alteración acelerada [3]. En este artículo se proponen los mecanismos de alteración a través de los cuales actúan los diversos factores de alteración presentes en dicho monumento.

\section{ACCIÓN DEL AGUA [4-6]}

\subsection{Procesos químicos}

Los procesos químicos de alteración de materiales pétreos sólo son posibles en presencia de agua; ciertamente, si el agua no está presente:

\section{INTRODUCTION}

In previous articles, the macroscopical morphology of alteration [1], the stone characterization and the alteration processes [2] and the evaluation of the behaviour to accelerated laboratory tests for the stones used in the Cathedral of Granada have been considered [3]. In this work, the alteration mechanisms through the alteration factors actuate have been proposed.

\section{WATER ACTION [4-6]}

\subsection{Chemical processes}

The chemical processes of alteration on the stony materials are only possibles in presence of water; if water are not present: 
- no son posibles las reacciones químicas entre los distintos componentes de la piedra,

- los procesos de migración y disoluciónrecristalización de sales solubles no pueden ocurrir, y

- la acción de los contaminantes atmosféricos es de escasa importancia.

Se pueden distinguir dos tipos de procesos químicos debidos al agua que actúan en la Catedral de Granada: corrosión y oxidación de hierros.

\subsubsection{Corrosión}

La piedra de Santa Pudia, debido a su composición química y su estructura altamente porosa, sufre un proceso natural de corrosión por ataque químico del $\mathrm{CO}_{2}$ disuelto en el agua que pasa a través de sus poros. Esta circulación de agua implica una disminución de la cohesión del material debida a procesos de solubilización. Las sales solubles disueltas son transportadas hacia la superficie y cristalizan cuando el agua se evapora; este proceso natural de recristalización ha sido descrito en estudios previos realizados por microscopía electrónica de barrido [4]. Por efecto de este proceso pueden apreciarse con frecuencia en los materiales pétreos tres zonas bien diferenciadas: una costra superficial, una zona intermedia de baja cohesión y una zona interna de material inalterado.

El $\mathrm{SO}_{2}$, disuelto en agua como $\mathrm{H}_{2} \mathrm{SO}_{3}$ ó $\mathrm{H}_{2} \mathrm{SO}_{4}$ (fruto de procesos catalíticos), actúa disolviendo el material en su superficie y en las partes internas del mismo que pueden ser alcanzadas por el agua (función de su porosidad). En las piedras de Santa Pudia se ha producido, en general, una importante sulfatación de la superficie, que ha progresado hasta mayor profundidad en los relieves arquitectónicos, especialmente en las cresterías, debido a su mayor superficie de exposición, así como a la mayor fragilidad de las superficies tratadas de forma mecánica. En las superficies no expuestas a la lluvia y en zonas protegidas tales como los bajos de las cornisas, pero mojadas periódicamente por percolación, el ataque químico es mucho más intenso. Existen en la Catedral de Granada un elevado número de cornisas con pendiente negativa, lo que provoca la acumulación de agua en sus partes internas. La ascensión capilar de agua, así como la condensación de vapor de agua conduce a los mismos procesos.
- chemical reactions between the stone components are not possible,

- the migration and disolution-crystallization processes of the water soluble salts do not can to occur, and

- the action of the atmospheric pollutants are of small importance.

On the stones of the Granada Cathedral we can to distinguish two chemical processes bound to the water action: corrosion and iron oxidation.

\subsubsection{Corrosion}

The Santa Pudia stone, for its chemical composition and high porous structure suffer a natural corrosion by chemical attack of the $\mathrm{CO}_{2}$ dissolved in water which permeates througth the pores. The water circulation implies a cohesion decrease due to the solubilization processes. The soluble salts are transported to the surface and precipite when the water evaporates; this natural recrystallization has been described in the previous SEM studies [4]. By this process, three different zones can be shown: a surface croust, a medium zone of less cohesion and the internal unaltered material.

The $\mathrm{SO}_{2}$ dissolved in water as $\mathrm{H}_{2} \mathrm{SO}_{3}$ or $\mathrm{H}_{2} \mathrm{SO}_{4}$ (catalytic processes) actuates dissolving the material in the surface or in the internal parts when the water permeates (porosity function). In the Santa Pudia stones, an important surface sulphatation has been produced that has been penetrated into the architechtonical relieves, crenellations specially, for their major expossition surface and for the major weakness of the surfaces mechanically treated. On the rain non-exposed surfaces and on the protected zones, as the lower of the cornices, but periodically damped by leaking out, the chemical attack is more intense. In the Cathedral of Granada, an high number of cornices are negative slope which provokes the water acumulation in the internal parts. The water capillar ascent and water vapour condensation also conduct to the same processes. 
El agua saturada de $\mathrm{CO}_{2}$ que resbala por los muros provoca una progresiva disolución de la calcita por formación de $\mathrm{Ca}\left(\mathrm{HCO}_{3}\right)_{2}$, más intensa en aquellas zonas donde se han producido estancamientos de agua, lo que ha favorecido una lenta percolación con el resultado de actuación a mayor profundidad.

Las superficies más expuestas a las lluvias, en principio más susceptibles de sufrir ataque por agua o soluciones ácidas, al no retener el agua durante largos períodos de tiempo y ser lavadas intensamente, por lo que no existen grandes depósitos salinos, presentan un estado de conservación generalmente satisfactorio.

Es frecuente el proceso de alteración alveolar sobre la piedra de Santa Pudia, debido principalmente a fenómenos de cristalización de sales en zonas muy ventiladas o expuestas a los vientos.

La compacta piedra de Sierra Elvira, presenta frecuentemente descamaciones y exfoliaciones debido a la naturaleza estratificada del material. Los procesos de corrosión actúan preferentemente sobre los planos de estratificación, lo que favorece la aparición de los mencionados indicadores de alteración. No obstante, la alteración más característica de la piedra de Sierra Elvira consiste en su fragmentación con separación de trozos compactos de carácter isomático.

\subsubsection{Corrosión de hierros}

Un importante proceso de alteración en la Catedral de Granada es la corrosión de los elementos de hierro usados para reforzar los elementos ornamentales de piedra. En ciertos casos, estos elementos metálicos han sido empleados con el ánimo de reforzar algunas estructuras pétreas en muy avanzado estado de alteración.

Los productos de la oxidación del hierro ocupan mayor volumen que el metal original; la expansión volumétrica teórica de este proceso oscila entre un $150-250 \%$ [7]. Diversos autores [8-10] han establecido los mecanismos de formación de los productos de la corrosión del hierro. En las fases iniciales, los materiales pétreos que rodean al elemento metálico pueden deformarse o romperse en los puntos de mayor presión; al continuar el proceso de corrosión, el incremento de presión llega a provocar la fracturación total. Las grietas formadas pueden ser la vía para una nueva penetración de agua con el consiguiente incremento en los procesos de corrosión.
The sliping up of satured $\mathrm{CO}_{2}$ water on the walls provokes a progressive disolution of the calcite by $\mathrm{Ca}\left(\mathrm{HCO}_{3}\right)_{2}$ formation, more intense on the zones where a water stagnancy has been produced which has been made easy the slow percolation and the depth actuation.

The more rain exposed stone surfaces, at first more capable of the water or acid solutions attack, are not retained the water for long periods of time and the salts deposits have been frequentely washed by the rain water and then their conservation state are generally satisfactory.

It is frequent the alveolar alteration of the Santa Pudia stones due principally to salt crystallization phenomena on very ventilated or wind exposed zones.

The compact Sierra Elvira stone presents frequentely chipping and exfoliation due to the stratified nature of the material. The corrosion actuates preferably on the stratification planes which favours the alterations previously mentioned. However, the more characteristic alteration of the Sierra Elvira stone is the fragmentation with separation of compact fragments of isomatic character.

\subsubsection{Iron corrosion}

An important alteration process in the Cathedral of Granada is the corrosion of the iron elements used for the reinforcement of ornamental stone elements. In certain cases the iron elements have been employed with the aim to reinforce some stony structures in very advanced alteration degree.

The last iron corrosion products occupy major volume that the original metal; the theorical volume expanssion of this process is $150-250 \%$ [7]. Diverse authors [8-10] have been established the mechanisms of formation of the corrosion products of the iron elements. In the initial phases, the stony material which round the metallic element can to bend or crack in the pressure points, when the corrosion continues, the pressure increases provoke the total cracking. The cracks formed can be the way for new water penetration and the consequent increase of the corrosion processes. 
Todos los elementos metálicos, externos o internos a las piedras, usados originalmente en la Catedral de Granada, presentan un muy avanzado estado de corrosión; éstos, y aquellos otros usados en algunas "restauraciones" han contribuido de forma muy significativa al estado de ruina de la mayor parte de los elementos ornamentales, y muy particularmente a la de los pináculos.

\subsection{Procesos físicos}

El agua es una importante fuente de acciones físicas de importancia en los procesos de alteración. El agua puede ejercer importantes acciones mecánicas como lluvia o granizo; no obstante, las principales acciones físicas deben ser atribuidas a procesos de hielo/deshielo y cristalización de sales.

La mayor parte del agua procede de la lluvia; en los muros expuestos al viento favorece su penetración. Otra vía de penetración de agua es el ascenso capilar desde el subsuelo, muy importante en las zonas bajas del edificio. El vapor de agua presente en la atmósfera penetra en el interior de los poros, y una cierta cantidad permanece en función de la humedad relativa del aire.

Es importante poner énfasis en el hecho de que los más importantes procesos de alteración debidos a la acción del agua tienen lugar durante el proceso de secado de los materiales pétreos.

\subsubsection{Cristalización de sales solubles}

El agua presente en las piedras puede contener numerosas sustancias procedentes de la atmósfera, el suelo, presentes ya en las canteras o como consecuencia de reacciones químicas. Cuando disminuye el contenido de agua por debajo de su valor crítico, el frente de agua líquida se retrae, con lo que se incrementa la concentración salina, y como resultado ocurren los procesos de cristalización de sales. Estas cristalizaciones pueden ocurrir tanto en la superficie como en el interior de la piedra, a profundidades variables, dependiendo de las solubilidades de las sales presentes, de la velocidad de la evaporación del agua y de la textura del material.

La cristalización en la superficie, eflorescencias, se produce cuando hay una baja ventilación, lo que indica que la velocidad de evaporación es más baja que la velocidad de migración capilar hacia el interior de la piedra. Los cristales se
All the original metallic elements used in the Cathedral of Granada, external or internal to the stones, show a very advanced corrosion degree; those elements and those used in certain "restoration" contribute to the actual state of ruin of the major part of the ornamental stones.

\subsection{Physical processes}

The water is an important source of physical actions with important influence on the alteration processes. The water can to exercise some mechanical actions as rain or hail; however, the more important physical actions must be atributed to freeze/thaw and salts crystallization processes.

The major part of the water has a rain provenance, the walls exposed to the wind favour the penetration. An other way of water penetration is the capillar ascent from the subsoil, very important in the lower zones of the building. The water vapour present in the atmosphere penetrates into the pores and a certain quantity remains in function of the air relative humidity.

It is important to emphasize that the more important alteration processes due to the water action occur during the driying process.

\subsubsection{Soluble salts crystallization}

The water present into the stones can to contain numerous substances coming from the atmosphere, the soil, the original stone or from chemical reactions. When the water critical content is hard up, the liquid water front withdraws, the saline concentration increases and the crystallization of the soluble salts occurs. The salts crystallizations can to occur on the surface or into the stone depending to salt solubilities, the velocity of the water evaporation and the texture of the material.

The crystallization on the surface, efflorescences, is produced with slow ventilation which implicates that the evaporation velocity is more slow that the velocity of the water capillar migration from the interior of the stone, the crystals are formed 
forman principalmente fuera de los poros, por lo que, generalmente, no se producen fuertes tensiones que puedan conducir a rupturas del material.

Cuando ocurre cristalización dentro de los poros, la superficie del material se encuentra seca y el frente de agua se encuentra dentro de la piedra a cierta profundidad; las cristalizaciones conducen a la formación de subeflorescencias y criptoeflorescencias. Los cristales formados ejercen presiones de cristalización e hidratación, lo que provoca la desagregación de una capa superficial, formación de ampollas o exfoliación.

La presión de hidratación se puede calcular por medio de la expresión:

$$
P_{h}=\left[n R T /\left(V_{h}-V_{0}\right)\right] \ln \left(P_{0}-P_{h}\right)
$$

donde:

$\mathrm{P}_{\mathrm{h}}=$ presión de hidratación (atm); $\mathrm{n}=$ número de moléculas de agua ganadas en la hidratación; $\mathrm{R}=82,07 \mathrm{ml} \mathrm{atm} / \mathrm{mol} \mathrm{K} ; \mathrm{T}=$ temperatura absoluta $(\mathrm{K}) ; \mathrm{V}_{0}=$ volumen original de la sal $(\mathrm{ml} / \mathrm{mol}) ; V_{h}=$ volumen del hidrato $(\mathrm{ml} / \mathrm{mol})$; $P_{0}=$ presión parcial del vapor de agua (atm); $P_{h}=$ presión de vapor del hidrato (atm).

Un tipo particular de subeflorescencia es la alteración alveolar [11], debida a la presencia de sales muy solubles e higroscópicas, capaces de intercambiar rápida y frecuentemente vapor de agua con el aire; en las zonas alteradas ocurren turbulencias de aire, y el viento actúa como un vector de humedad y temperatura.

En la Catedral de Granada, aparecen eflorescencias de tipo calcítico, y más frecuentemente de yeso debido a la contaminación ambiental por $\mathrm{SO}_{2}$.

Los resultado obtenidos en el estudio del edificio pueden resumirse en:

a) La presencia y naturaleza de las sales solubles es independiente del tipo de piedra.

b) Las eflorescencias aparecen preferiblemente en invierno, desapareciendo casi en su totalidad en verano.

c) La formación de eflorescencias se da preferiblemente en: límite superior del ascenso capilar del agua, zonas inferiores de las cornisas, terrazas enlosadas, desagües defectuosos y zonas adyacentes a piedras con baja retención de agua. principally outside of the pores and the breack effects are generally very little.

In the crystallization into the pores, the surface of the wall is dry and the water front is into the stone at certain depth; the salts crystallization produces subfflorescences and criptofflorescences. The crystals exercice crystallization and hydratation pressures which provoke a disagregation of the surface layer, bubble formation or exfoliation.

The hydratation pressure can be calculated by the expression:

$$
P_{h}=\left[n R T /\left(V_{h}-V_{0}\right)\right] \ln \left(P_{0}-P_{h}\right)
$$

where:

$P_{h}=$ hydratation pressure (atm); $n=$ number of water molecules gaigned in the hydratation; $R=82.07 \mathrm{ml} \mathrm{atm} / \mathrm{mol} \mathrm{K} ; T=$ absolute temperature (K); $V_{0}=$ original salt volume $(\mathrm{ml} / \mathrm{mol}) ; V_{h}=$ hydrate volume $(\mathrm{ml} / \mathrm{mol}) ;$ $P_{0}=$ partial pressure of water vapour (atm); $P_{h}=$ vapour pressure of the hydrate (atm).

A particular type of subefflorescence is the alveolar erosion [11], due to the presence of very soluble and hygroscopical salts, capable of a fast and frequent water vapour exchange with the air; in the altered zones exist fast wind turbulences, and the wind actuates as warmth and humidity vector.

In the Cathedral of Granada, calcite efflorescences and more frequntely gypsum efflorescences due to the $\mathrm{SO}_{2}$ pollution, have been detected.

The results obtained in the study can be summed up in:

a) The presence and nature of the soluble salts are independient of the stone type.

b) The presence and nature of the soluble salts are independient of the stone type.

c) The efflorescence formation occur preferably in: upper limit of water capillar ascent, lower zones of the cornices, tiled roofs and faulty pipes, and adjacent zones to waterproof structural stones. 
d) Las sales solubles distribuidas por extensas zonas pueden concentrarse en zonas localizadas de poca extensión por acción de la lluvia, provocandose una alteración acelerada. La migración de sales ocurre durante y después de los períodos de lluvia.

e) Las sales higroscópicas cristalizan periódicamente en función de las oscilaciones de temperatura y humedad relativa.

\subsubsection{Mecanismos de heladicidad}

Los indicadores de alteración más característicos de las piedras de la Catedral de Granada debidos a procesos de congelación/deshielo son fracturación, separación de placas o películas y exfoliación; no obstante, es necesario hacer notar, de acuerdo con la literatura y los ciclos de alteración acelerada realizados con anterioridad [3], que la fracturación es el indicador de alteración más frecuente en los tests de alteración acelerada, mientras que en el monumento aparece con más frecuencia la separación de placas.

Cuando el agua líquida a $0^{\circ} \mathrm{C}$ cambia a hielo, se produce un incremento de volumen del $9 \%$. Si el agua se encuentra dentro de poros o pequeñas grietas, la presión de expansión puede dañar la piedra. Las oscilaciones térmicas en invierno favorecen esta alteración. Otros factores que contribuyen a este mecanismo de alteración son la humedad relativa ambiental, el alto coeficiente de saturación de las piedras (debido a su alta porosidad) y las características porosimétricas de las mismas [12].

Las fracturas producidas o aumentadas por estos procesos en las piedras de Sierra Elvira colocadas sobre las cornisas favorece además otras accciones del agua, como ha sido comentado previamente.

\section{ACCIONES DE TIPO ANTROPOGÉNICO}

\subsection{Sulfatación}

La acción antropogénica más importante sobre la Catedral es la sulfatación. Aunque se han descrito tres mecanismos diferentes para la sulfatación de las piedras [13-15], las características medioambientales y de las piedras de la Catedral de Granada, permiten establecer que el más importante es la oxidación del dióxido de azufre en fase acuosa sobre la superficie de la piedra.

Los gradientes de humedad y temperatura en la d) The total soluble salts distributed on extensive zones can to concentrate on small zones by rain action provoking an accelerated alteration. Salts migration occurs during and after the rain periods.

e) The hygroscopical salts crystallize periodically according to the relative humidity and temperature oscillations.

\subsubsection{Frost mechanisms}

The indicators of alteration more characteristics due to freeze/thaw processes on the stones of the Cathedral of Granada are cracking, contour scaling and exfoliation; however, it is necessary to denote according to the literature and the accelerated alteration tests previously described [3], that the cracking is more frequent in the accelerated tests whereas the monument stones show preferably contour scaling.

When the water at $0^{\circ} \mathrm{C}$ change to ice, a volume increase of $9 \%$ occur. If the water is into pores or small cracks, the expanssive strength can to damage the stone. The daily thermic oscillations in winter favour this damage. An other factors which contribute to this alteration mechanism are the air relative humidity, the high saturation coefficient of the stones (due to the high porosity) and its porosimetric characteristics [12].

The cracks produced/increased by these processes in the Sierra Elvira stones located upper the cornices favour the water actions as we have comented previously.

\section{ANTHROPOGENICAL ACTIONS}

\subsection{Sulphatation}

The most important anthropogenical action on the Cathedral of Granada is the sulphatation. Although three different mechanisms have been described for the sulphatation of the stones [13-15], the environmental and stones characteristics permit to establish that the more important is the sulphur dioxide oxidation in aqueous phase on the stone surface.

The temperature and humidity gradients closely 
proximidad de la superficie de la piedra contribuyen a que el $\mathrm{SO}_{2}$ pase a la película líquida sobre la superficie de la piedra; esta solución penetra hacia el interior en función de su cantidad y de las características de porosidad de la piedra. La transferencia del dióxido de azufre a la piedra es muy rápida, y su oxidación ocurre en presencia de partículas carbonosas y elementos metálicos presentes sobre la superficie, que actúan como catalizadores.

\section{FACTORES DE INCOMPATIBILIDAD}

\subsection{Corrosión de hierros} (descrita previamente)

\subsection{Presencia de morteros ricos en sales solubles}

Los efectos de las sales solubles han sido descritos en detalle con anterioridad; si los morteros empleados, fundamentalmente en ciertas "restauraciones" antiguas, contienen altas cantidades de sales solubles, éstas pueden migrar hacia las piedras adyacentes.

\section{OSCILACIONES TÉRMICAS}

En la Catedral de Granada, las oscilaciones térmicas tienen gran importancia en los procesos de alteración, generalmente cuando también se hallan implicados procesos de heladicidad. En los materiales de Sierra Elvira, extremadamente compactos, las oscilaciones térmicas pueden provocar el incremento de tamaño y profundidad de las microfracturas originales de estos materiales. Los autores han realizado con anterioridad estudios sobre la influencia de las oscilaciones térmicas sobre materiales muy compactos tales como el mármol $[16,17]$.

\section{SEISMICIDAD}

Los terremotos provocan la aparición de fisuras en las piedras que, además de sus consecuencias de tipo estructural, son nuevas vías para la penetración del agua. Generalmente aparecen en materiales sometidos a tensiones estructurales.

\section{FACTORES BIOLÓGICOS}

Se ha de tener presente la influencia que sobre la estabilidad de la piedra tiene la presencia de determinadas formas de vida, tanto animales como vegetales. Las plantas superiores que the stone surface contribute to the $\mathrm{SO}_{2}$ passes to the liquid film on the stone surface, this solution penetrates to the interior in function of the solution quantity and the stone porosity characteristics. The sulphur dioxide transference to the solution is very fast, and the oxidation occurs in presence of carbonous particles and metallic elements present on the surface which actuate as catalists.

\section{INCOMPATIBILITY FACTORS}

\subsection{Iron corrosion}

(Previously described)

\subsection{Presence of mortars rich in soluble salts}

The effects of the water soluble salts have been previously described; if the mortars employed, fundamentally in certain "restorations", have a high soluble salts content, they can migrate to the adjacent stones.

\section{THERMIC OSCILLATIONS}

At the Cathedral of Granada, the thermic oscillations have importance on the alteration processes generally when implie freeze/thaw processes. In the compact materials from Sierra Elvira, the thermic oscillations can to provoke the increase of the original microcracks, some studies about the influence of thermic oscillations on very compact materials like marble have been carried out by the authors $[16,17]$.

\section{SEISMICITY}

The earthquake actions provoke the appearance of fissures in the stones which, moreover of the structural consequences, are new ways for the water penetration. Generally appear in materials submited to structural tension.

\section{BIOLOGICAL FACTORS}

It is important to consider the influence of some biological agents, animals and vegetables, on the stone stability. The vegetation which frequently grow on the crevices have some undesirable 
crecen con frecuencia en todo tipo de hendiduras tienen varios efectos indeseables: aparte de su efecto disgregante por penetración de las raíces, éstas provocan reacciones químicas en el sustrato, así como retención de humedad, factor éste de gran importancia para el progreso de la mayor parte de las reacciones químicas. Algas, musgos y líquenes tienen también efectos parecidos, pero sin el poder disrrompiente de las raíces, que no poseen; la presencia de oxalatos en la superficie de la piedra se asocia generalmente a la presencia de líquenes.

Es muy frecuente la proliferación de aves en estas antiguas edificaciones, generalmente palomas, cuyos excrementos, además de producir un desagradable efecto estético, por su composición y carácter ácido, provocan reacciones en los materiales pétreos con formación, esencialmente de fosfatos.

\section{AGRADECIMIENTOS}

Este trabajo ha sido realizado con una subvención de la D.I.C.Y.T. effects: the dissagregant effect of their roots, the chemical reactions provoked by the roots on the substrat, and the humidity retention, of special importance on the progress of the chemical reactions. The algae, mosses and lichens have similar effects, but the absence of roots do not provoke dissagregation phenomena; the presence of oxalates on the stone surfaces generally indicates chemical reactions associated to the lichens.

It is very frequent the proliferation of birds, pigeons generally, on these ancient buildings, which dirts with aesteticcal effects also provoke chemical reactions on the stone due to their composition and acid character, with formation of phosphates esentially.

\section{ACKNOWLEDGEMENT}

This work has been realized with a D.I.C.Y.T. subvention.

\section{REFERENCIAS}

[1] ALCALDE, M.; MARTIN, L.; BELLO, M. A.; MARTIN, A.: "Macroscopical morphology of deterioration of the stone used in the Cathedral Whole of Granada (Spain)", Materiales de Construcción, Vol. 42, No. 226, 1992, 27-48.

[2] MARTIN, L., BELLO, M. A. and MARTIN, A.: "Stone characterization and alteration processes of the Cathedral of Granada (Spain)", Proceedings 7th Intern. Cong. on Deterioration and Conservation of Stone, Lisboa (Portugal), 15-18/06/02, 1499-1506.

[3] IBID: "Aceleratted alteration tests on the stones used in the Cathedral of Granada (Spain)", Proceedings 7th Intern. Cong. on Deterioration and Conservation of Stone, Lisboa (Portugal), 15-18/06/92, 845-850.

[4] AMOROS, G. G. and FASSINA, V.: "Stone Decay and Conservation". Ed. Elsevier, 1983, Amsterdam.

[5] LEWIN, S. Z. and CHAROLA, A. E.: "Scanning electron microscopy in of 'diseased' stone". Scanning Electron Microscopy, vol. $1,1979,695-703$.

[6] MARTIN, A.: "Ensayos y experiencias de alteración en la conservación de obras de piedra de interés histórico artístico". Ed. C.E.U.R.A., 1990, Madrid.

[7] WINKLER, E. M. "Stone properties, durability in man's environment". Ed. Springer-Verlag, 1975, Vienna.

[8] MISAWA, T., MASHIMOTO, K. and SHIMODAIRA, S.: "The mechanism of formation of iron oxide and hydroxides in aqueous solutions at room temperature". Corros. Science, vol. 14, 1974, 131-149.

[9] BERNAL, J. D., DASGUPTA, D. R. and MACKAY, A. L. "The oxides and hydroxides of iron and their structural relationships". Clay Mineral Bulletin, 4, 1959, 15-30.

[10] CLARKE, E. J.: "Radiography of ancient structures on the Acropolis of Athens. Mapping/evaluating the metal joints \& reinforcement of marble monuments". Technology \& Conservation, 3/83, 1983, 18-22.

[11] PAULY, J. P.: "Maladie alveolaire. Conditions de formation et d'evolution". Procc. Int. Symp. on Conservation of Stone, Bologna, $1975,55-79$.

[12] ANONYMOUS: "La gélivité des pierres et des bétons". Ed. Centre Experimentale de Recherches et d'Etude du Bâtiment et des Travaux Publics (CEBTP), 1963, Paris. 
[13] CALVERT, J. G.; SU, F.; BOTTENHEIM, J. W. and STRAUSZ, O. P.: "Mechanism of the homogeneous oxidation of sulphur dioxide in the troposphere". Atmospheric Environment, 12, 1978, 197-226.

[14] EGGLETON, A. E. and COX, R. A.: "Homogeneous oxidation of sulphur compounds in the atmosphere". Atmospheric Environment, 12, 1978, 227-230.

[15] SIDE-BOTTOM, H.: "Photoxidation of sulphur dioxide". Procc. 1st European Symp. on the Physico-Chemical Behaviour of Atmospheric Pollutants, Ispra, 1979, 247-253.

[16] BELLO, M. A.; MARTIN, L.; MARTIN, A.: "Scanning electron microscopy to establish the marble weathering mechanism in the Alhambra of Granada (Spain)", Scanning Microscopy, Vol. 5, No. 3, 1991, 645-652.

[17] BELLO, M. A.; MARTIN, L.; MARTIN, A.: "Decay and treatment of Macael white marble", Studies in Conservation, Vol. 37, No. 3, 1992, 193-200

\section{publicaciones del ICCET/CSIC}

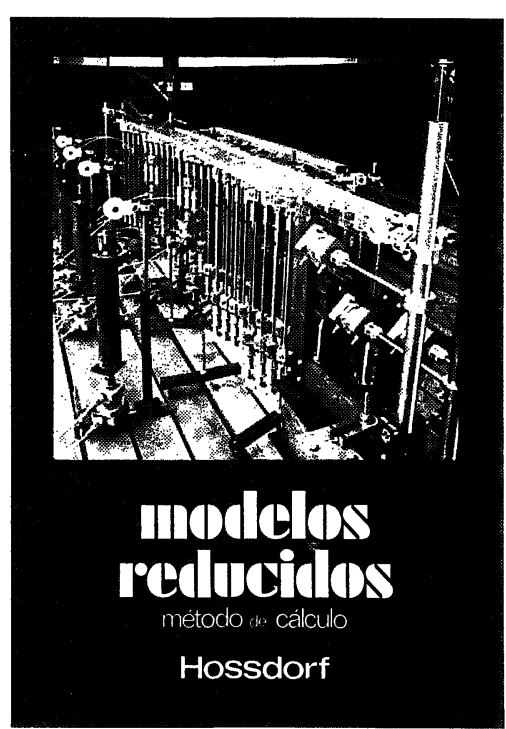

Modelos reducidos. Método de cálculo

H. Hossdorf, Ingeniero Civil

La técnica de los ensayos en modelos reducidos de estructuras sufre hoy dia una decisiva metamorfosis Hasta hace poco era un medio más bien de aresa nia, que no siempre era tomado en serio por los

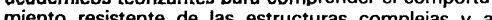
mue que se acudín las más de las veces, como a un cias. Sin embar cias. Sin embargo, en poco ingo y gracias a su conexión con los ordenadores digitificam, se ha trans. auedo

Un volumen encuadernado en cartoné plastificado con lomo de tela de $17 \times 24 \mathrm{~cm}$, compuesto de 250 páginas, 158 figuras y fotografias.

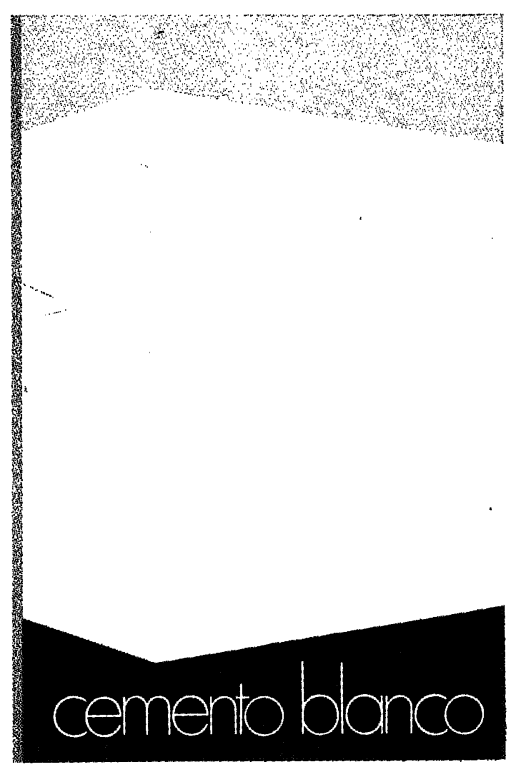

Cemento blanco

Julián Rezola

Ingeniero Quimico Dipl. I. Q. S

Sabido es que existe una extensa y documentada bibliografia sobre el cemento gris: en cambio, no puede decirse lo mismo acerca del cemento portland blanco, ya que los escritos existentes se refieren tan sólo a algunas peculiaridades que le distinguen de aquél.

El autor nos ofrece sus profundos conocimientos y su larga experiencia tanto en laboratorio como en fabricación.

La parte descriptiva del libro se complementa con gráficos, diagramas y fotografias de gran utilidad, destinados a conseguir la aplicación apropiada de este aglomerante.

Un volumen encuadernado en cartoné policerado, de $17.4 \times 24,3 \mathrm{~cm}$, compuesto de 395 páginas, numerosas figuras, tablas y ábacos.

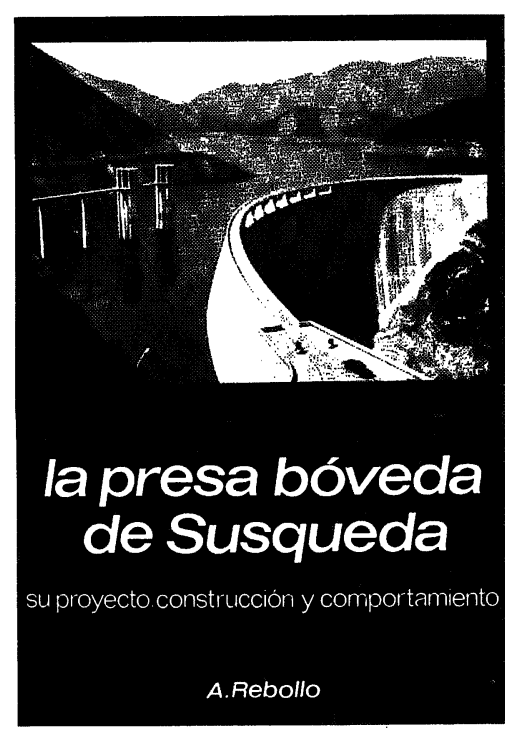

La presa bóveda de Susqueda A. Rebollo, Dr. Ingeniero de Caminos

El esfuerzo del constructor de presas se sitúa por su pretension de perennidad, a contracorriente de las tendencias de la civilización actual, caracterizada por lo fungible. Pueden evocarse las 10.000 grandes. presas en funcionamiento o en construcción que estan envejeciendo y reclaman los cuidados gerontológicos para mantener $y$ perfeccionar su servicio y garantizar su inalienable pretensión de perennidad. En la medida en que todas nuevas obras, grandes o pequeñas, son portadoras de riesgos ecológicos $y$, a veces, catastróficos, que aumentan con el envejecimiento, la gerontologia de las presas es todo un emplazo. La acción adelantada de Arturo Rebollo en este terreno marca un camino a seguir para todos los que aman su propia obra con la devoción paternal que èl ha puesto en Susqueda.

Un volumen encuadernado en cartone plastificado con lomo de tela, de $18 \times 24.5 \mathrm{~cm}$, compuesto de 408 páginas, 330 figuras y fotografias y 39 tablas. 